\title{
MOZAMBIQUE, NEOLIBERAL LAND REFORM, AND THE LIMPOPO NATIONAL PARK*
}

\author{
ELIZABETH LUNSTRUM
}

\begin{abstract}
Central to its transformation from a state-centered to a neoliberal, free-market economy, in 1997 the Mozambican state passed a radical new land law that guarantees the rights of individuals and communities to occupy land and transfer land-use titles, a move seen as necessary for attracting private investment. By comparing how the land law has been applied to the Limpopo National Park and several adjacent villages, I show how it has led to geographically uneven land reform. More specifically, outside the park, the law has enabled the semiprivatization of community lands, in theory protecting community land rights. However, the application of the law within the park has resulted in the further nationalization of this space, which is leading to land dispossession for communities within the park's borders. I thus show how neoliberal land reform is giving rise to a seemingly contradictory type of "neoliberal state space." Keywords: Great Limpopo Transfrontier Park, Limpopo National Park, Mozambique, neoliberal land reform, privatization.
\end{abstract}

$S_{\text {in }}$ ince the end of the Mozambican civil war in the early 199os, the Mozambican state has undergone a profound transformation in which it has abandoned many features of its state-centered economy in favor of a free-market, capitalist economy. Central to this transformation, in 1997 the state passed a radical new land law (Lei de Terras, Lei No. 19/97), which guarantees the rights of individuals and communities to occupy and develop land and transfer land-use titles. Neoliberal reformers saw such restructuring of the land-tenure system, which amounts to the semiprivatization of land and natural resources, as necessary for attracting private, mainly foreign, investment. In this article I analyze the promises, ambiguities, and impacts of the 1997 land law in the context of Mozambique's Limpopo National Park (LNP) -a project that has enabled significant investment opportunities-and several adjacent villages. ${ }^{1}$ By comparing how the land law has been applied in these different spaces, I show how it has led to geographically uneven land reform. More specifically, the law has enabled the land occupied by communities outside the LNP to be semiprivatized, a move that has appeared to protect their land rights. As the law has been applied inside the park, however, it has enabled the further nationalization of this space, which is leading to land dispossession for those living inside park borders.

After describing the neoliberal economic and political context out of which the land law emerged, I turn to the LNP, examining the significance of the park for national development as well as how the land law has both enabled communities living near the park to protect their land-use claims and provided the legal condi-

\footnotetext{
* I thank Joshua Barkan, Bruce Braun, Megan Casey, and two anonymous reviewers for their insightful comments on earlier drafts of this article. The Fulbright Foundation provided funding for this project, as did the University of Minnesota's Interdisciplinary Center for the Study of Global Change and Department of Geography.
}

De Dr. Lunstrum is an assistant professor of geography at York University, Toronto, Ontario, Canada M3J 1 P3. 
tions necessary for building decentralized, community-based development projects tied to the park. I then show how the land law exempts the space of the LNP from having to recognize community rights to use and benefit from the land as well as hold transferable land-use titles. Juxtaposing the park with the communities outside its borders in this way allows me to illustrate the uneven geography of neoliberal land reform. I conclude by considering how this case speaks to larger concerns regarding state power and neoliberal reform, especially the privatization of land and natural resources. I demonstrate that this case both fits uneasily with and extends the insights of many contemporary analyses and critiques of neoliberal political, economic, and environmental reforms. First, many recent studies have shown that the privatization of land and natural resources often leads to dispossession, especially among the poor. In the case of the Mozambican land law, the semiprivatization of land as enabled by the law seems to protect community land rights. But the nationalization of parkland-intricately tied to broader, neoliberal economic reforms, as I will show-is what has resulted in land dispossession. Second, in recent years scholars have shown that neoliberal policies have not only led to the retreat of the state but have also brought about its restructuring and the consolidation of its power. Investigating how the land law has been applied to the LNP, we will see that state power is not merely consolidated over the park. More profoundly, the park emerges as a type of "neoliberal state space"; that is, a space over which the state is the ultimate arbiter, deciding who can enter this space, for what purposes, and so on.

\section{Background to the 1997 Land Law and Neoliberal Reform in Mozambique}

Upon independence from the Portuguese in 1975, the Marxist-Leninist Front for the Liberation of Mozambique (FRELIMo) came to power and set out to transform Mozambique into a "modern," single-party socialist state. Reflecting FrELIMo's socialist political platform, the 1975 Constitution nationalized all land and natural resources, meaning that only the state could determine the conditions under which citizens could access them. The 1979 land law reinforced this nationalization, which further prohibited the selling, renting, or mortgaging of land, as well as any other sort of alienation. As Jennifer Garvey explained, this law "decidedly placed the state's interests, economic, strategic or otherwise, before any citizen's rights or the more general public interest" $(1998,1)$. According to FRELIMO, such large-scale nationalization of land was needed to provide large areas of fertile land for state farms and to protect the subsistence base of rural communities by collectivizing agriculture and constructing communal villages (Bowen 2000; Tanner 2002).

Before FRELIMo could fully realize its plan of "socializing the countryside" through collectivization, Mozambique found itself in the throes of an intensely violent civil war, funded and fueled by apartheid South Africa. Because the conflict resulted in the concentration of state resources on defense rather than on development, in the disruption of the nation's transportation system and tourist economy, and in the slowing down of production, FRELIMo found itself in a precarious eco- 
nomic position. Facing economic collapse and reflecting the neoliberal economic trends that were beginning to sweep sub-Saharan Africa, FRELIMo's hopes for a flourishing socialist state were soon dashed. Although Mozambique was never entirely closed off to foreign investment, FRELIMo began to institute economic changes aimed at decentralization and limited privatization as it entered into negotiations with the International Monetary Fund. In 1987 FrELIMO accepted a comprehensive structural-adjustment package, known as the "Economic Rehabilitation Program," in which it agreed to devalue its currency, liberalize trade, reduce subsidies, and eliminate price controls on agricultural products, in part to promote the private sector and (limited) market activity (Bowen 2000; Pitcher 2002). On the political front, FRELIMO agreed to hold multiparty elections in 1994, thus ending its tenure as the single legally recognized political party in Mozambique.

If such neoliberal political and economic reforms effected limited market liberalization and multiparty elections, by the early 1990 s they equally opened space for contentious debates concerning reform of the land-tenure system, especially land privatization. The World Bank, the U.S. Agency for International Development (USAID), and many Mozambican elites-including some members of FRELIMO-were concerned that, as matters stood, the state held too much power over land and natural resources. This, they argued, jeopardized community rights to land and, more important, I would argue from their perspective, posed obstacles to marketbased development and the accumulation and circulation of capital generated by foreign investment, because foreigners would surely avoid investing in a political and economic context in which constitutional mandate foreclosed property rights. Yet critics of privatization, including high-ranking FRELImo officials, argued that the privatization of land, along with the introduction of freehold rights, would ultimately lead to landlessness and thus seriously harm the rural poor (Tanner 2002; Hanlon 2004).

Such debates over land reform were also framed by the fact that by 1992 the civil war had finally come to an end and thousands of refugees and internally displaced peoples (IDPS) were returning home. The government had tried to engineer this process of relocation, but it lacked the resources to implement such large-scale resettlement. Assisted by international donors, refugees and IDPs returned home with little incident and help-tactical or financial-from the state. Given that the customary land-tenure system had survived years of state intervention and civil conflict, it was clear that any new land legislation would have to take customary tenure patterns into account (Tanner 2002, 2005; compare Hanlon 2004).

Through extensive public debate among various arms of government, civil society organizations, and international aid organizations in what is widely regarded as an exemplar of democratic, public participation, Mozambique's new land law was finally approved in 1997 (Tanner 2001; Hanlon 2004). Although this law reconfirms that the state holds the ultimate ownership of all land, it has introduced a mechanism that protects the tenure rights of not only individuals but also communities that, through the law, have "automatic and overriding rights to the land they 
occupy" (Hanlon 2004, 605). And whereas communities and individuals cannot technically own the land, they can request that their land be delimited, in which case the state grants a certificate of occupancy; or they can choose to carry out a more intensive process of demarcation, which yields a formal title document. This amounts to a fundamental transformation of land-tenure relations, because landuse titles and rights are transferable. So, for instance, after consultation with a potential investor, an individual or community may choose to sell, rent, or lease its right to occupy, use, and benefit from the land and its resources. A formal land market has thus come into existence.

Truly a product of its time-born from neoliberal economic and political reform in a postwar, postsocialist context-the land law has emerged as a compromise between elite interests in privatizing land and more populist interests in protecting the rural poor and creating development opportunities that would help alleviate rural poverty. Hence the law serves multiple purposes. First, it acknowledges and protects existing rights to land based on prior occupancy. This is particularly significant in a country like Mozambique, where peace and political stability, along with the adoption of a market economy, have given land new value. As Maria da Conceição de Quadros explains,

The new economic situation, political stability and the low cost of land spurred a race for land titles by the urban elite and other economic agents. This situation created great insecurity in the countryside, where local people were visited by strangers who told them that, as of this moment, the land where they lived no longer belonged to them, because it had been allocated to others by decision of the authorities in Maputo or the provincial capital. (de Quadros 2003, 181-182)

The land law in this sense was designed to prevent land concentration or a largescale landgrab. In fact, when investors wish to invest in community land where a certificate or title has been issued, consultation with communities is mandatory under the law.

Second, as part of the state's broader commitment to decentralization, under the land law the state-at least in theory-devolves decision-making capacity over the land to the individuals or communities occupying it, allowing such parties to negotiate directly with private investors. This arguably limits the role of the state, refashioning it into one of a mediator or regulator as it "ensur[es] that minimum standards are applied in these negotiations, that registration complies with technical standards and that the taxation system functions effectively" (Norfolk 2004, 16).

Third, by protecting community land-use rights and opening avenues for communities to sell or otherwise transfer these rights, the land law works to promote and protect private-often foreign-investments, which are seen as central to generating capital and promoting economic development. The architects of the law recognized that investors are more likely to make investments if no ambiguity over land rights exists and if they can negotiate directly with the title-holding individual or community. For economic elites and proponents of larger neoliberal reforms, 
this step was necessary, not only to attract investment but also to begin integrating Mozambique into the global economy. At the community level, fostering an enabling investment environment through the land law was to help provide poor, rural settlements with intensely needed working capital by "unlocking" the value held in their land, allowing them to use it as a means of rural development and capital accumulation (Tanner 2002, 2005).

As the rationales behind the land law make clear, neoliberal land reform in Mozambique is not about the parceling of sizable tracts of land into smaller units to be redistributed to a larger number of people via market mechanisms, as is the case in Brazil (Wolford 2007), South Africa (Fraser 2007), and the Philippines (Borras 2005). This type of reform was not needed in Mozambique, for the vast majority of Portuguese left the country around the time of independence, precluding the colonial and explicitly racist patterns of land concentration and dispossession we see in South Africa and, until recently, Zimbabwe. Rather, land reform in Mozambique is primarily aimed at the (semi)denationalization and privatization of land and natural resources as a means of attracting investment. Because neoliberal land policy tends to prioritize property-rights regimes based on the premise that markets are the most efficient way of managing resources (Harvey 2005), the Mozambican land law is an instrument of neoliberal land reform, despite its obvious differences with land-reform legislation in countries like Brazil, South Africa, and the Philippines.

\section{The Limpopo National Park, the 1997 Land Law, and ECONOMIC DEVELOPMENT}

In the eyes of investors, not all land is created equal. As a new land market has emerged in Mozambique, locations conducive to ecotourism in such a relatively "pristine" (read "undeveloped") nation have caught the attention of investors (Tanner 2002; de Quadros 2003). Enabled by its mechanisms for land delimitation and registration, the land law has been used to provide rural communities with landuse titles in areas surrounding national parks, a first step in protecting community land rights and in realizing decentralized community-development projects linked to parks. Several of these projects exist along the edges of the LNP, where land values have increased exponentially since it was created in 2001 and integrated into the trinational Great Limpopo Transfrontier Park (GLTP) in 2002 (Figure 1).

Supporters assert that the LNP/GLTP will promote biodiversity and rehabilitate wildlife populations (because wildlife had been decimated during the civil war); encourage goodwill among the member nations of Mozambique, South Africa, and Zimbabwe; secure land rights of nearby communities; and promote both decentralized community empowerment and large-scale economic development via investment and tourist dollars (World Bank 1996; Magane and others 2003; GLTP 2008). This, say supporters, will benefit Mozambique in particular by enabling communities near the LNP to profit from the thriving tourist markets that spill across the South African border. In fact, critics of the project have speculated that the princi- 


\section{The Great Limpopo Transfrontier Park, within the Great Limpopo Transfrontier Conservation Area}

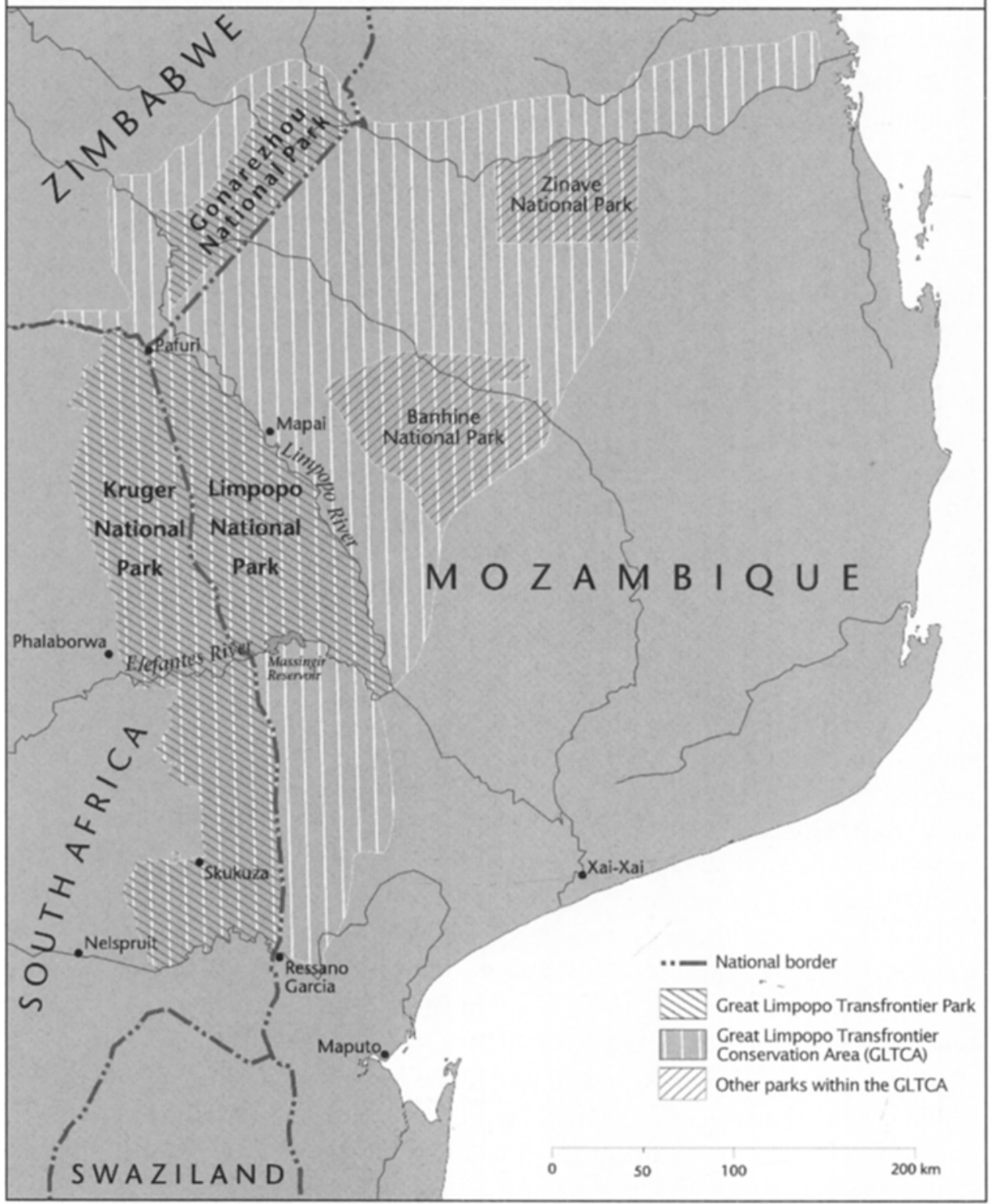

FIG. 1-The Great Limpopo Transfrontier Park in southeastern Africa comprises Mozambique's Limpopo National Park, South Africa's Kruger National Park, and Zimbabwe's Gonarezhou National Park. Sources: PPF 2007; SAHIMS 2008. (Cartography by Elizabeth Fairley, University of Minnesota Cartography Laboratory) 


\section{Mozambique's Massingir District and the Southern Part of the Limpopo National Park}

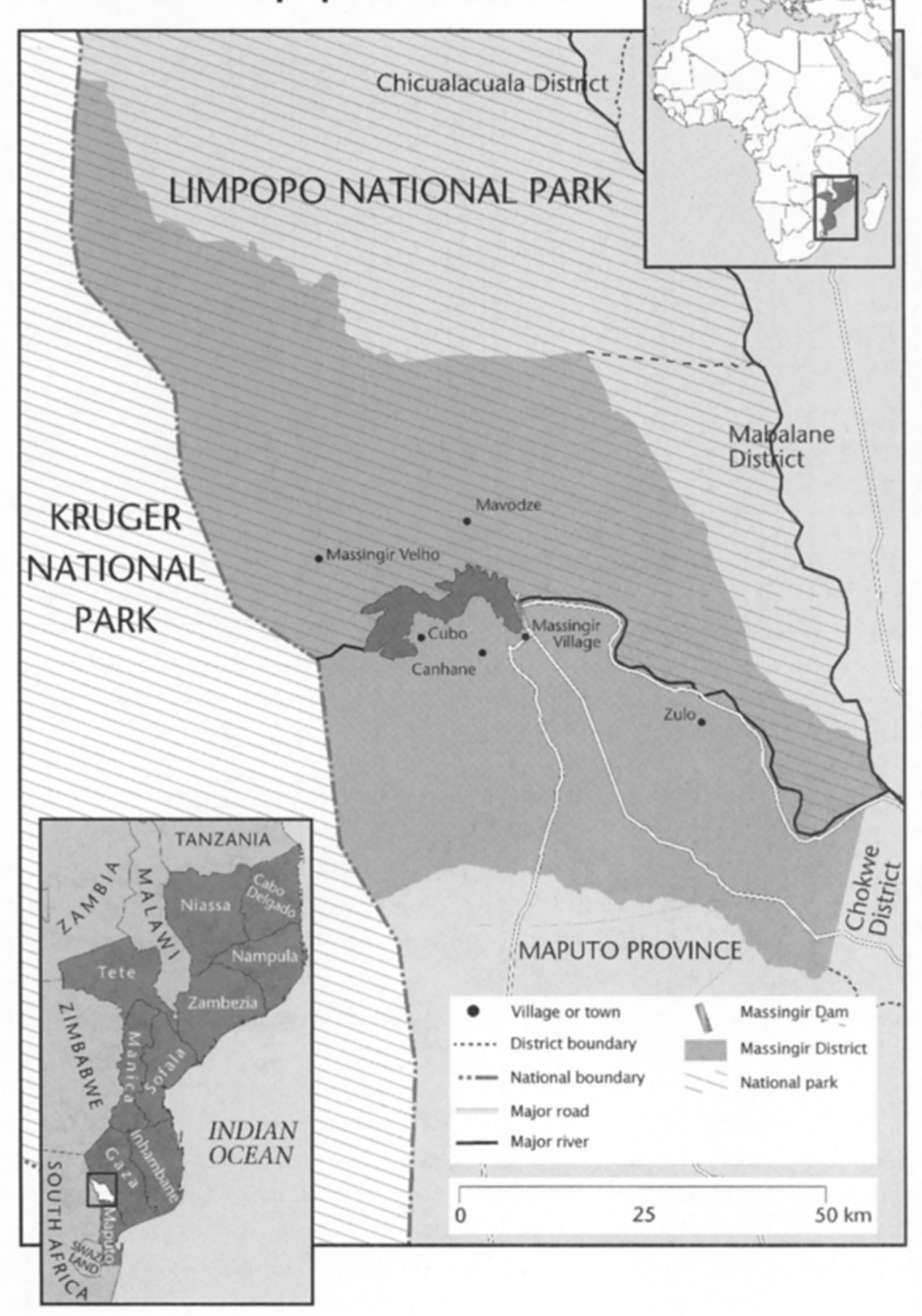

FIG. 2-The southern region of the Limpopo National Park, indicating the locations of the Massingir District and the villages of Canhane, Cubo, and Massingir Velho. Sources: ppF 2007; sayms 2008. (Cartography by Elizabeth Fairley, University of Minnesota Cartography Laboratory) 


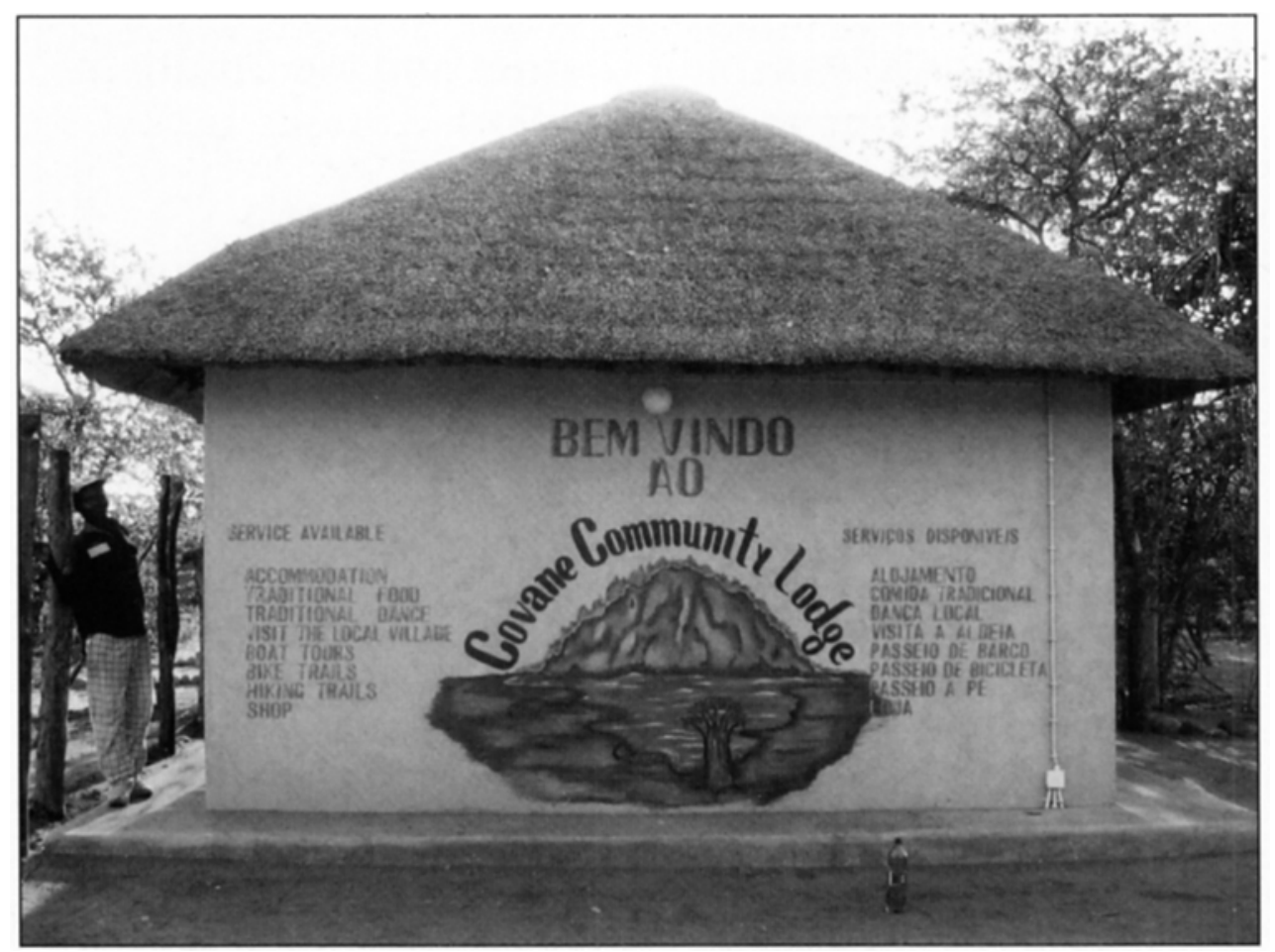

FIG. 3-The Mozambican community of Canhane opened the Covane Community Lodge, cofinanced by the Swiss nongovernmental agency Helvetas and the U.S. Agency for International Development, in 2004 to serve visitors to the Limpopo National Park. (Photograph by the author, February 2005)

pal rationale for the LNP is that it creates new investment opportunities. Kruger National Park-South Africa's contribution to the GLTP-is often filled to capacity with tourists-and large animals-but it cannot expand farther into South Africa. However, critics argue, Kruger can and indeed is expanding into Mozambique in the form of the LNP, creating significant investment opportunities along the way (compare Wolmer 2003).

The application of the 1997 land law has helped enable decentralized development projects in communities outside the LNP, particularly in Canhane and Cubo (Figure 2). In 2002, Helvetas, a Swiss nongovernmental organization (NGO), approached the residents of Canhane to discuss the possibility of opening a community-run lodge to house tourists visiting the LNP. After a series of community meetings with Helvetas, Canhane's members agreed to the project. They formed a steering committee and, with Helvetas's guidance, chose a site with panoramic views of the Massingir Reservoir and, beyond that, of the LNP, on which to build the lodge. Before construction began, Helvetas, following the delimitation procedures set out by the land law's technical annex, worked with Canhane and its neighbors in Cubo, Mongoe, and Tihovene (Massingir Village) to determine and map the boundaries of Canhane's land, delimiting an area of 7,024 hectares. ${ }^{2}$ Helvetas then helped the 
community apply for a title, later presented to the community leader, and legally secured and recorded the community's land rights (Helvetas 2002; Chauque 2004; Palalane 2005). After several months of construction, the Covane Community Lodge opened its doors to its first visitors in 2004 (Figure 3). Although Helvetas and USAID cofinanced the lodge (with an amount equal to U.S. $\$ 20,000$ and U.S. $\$ 50,000$, respectively), the people of Canhane own it, and they have the final word on what will happen to the lodge once Helvetas ends its financial, technical, and managerial support (which could happen later in 2008). At that time, the community has the option of running the lodge itself or finding a private investment partner; if the latter, the partner will have to negotiate with the community following the guidelines laid out in the land law.

During the course of seventy interviews in Canhane in 2004-2005, the vast majority of respondents voiced overwhelming support for the lodge. Much of their support was tied to the revenue the project was generating, revenue that to date had been dedicated to expanding the community's schoolhouse so that the older children would not have to learn outdoors. As Agnaldo Macia, one of the local teachers, added, "the children will benefit from this project, even the community will benefit. And it gives the community the responsibility to motivate more of its children to go to school" (2005). A number of residents also explained that future revenue would be spent on providing easier access to cleaner water, valued in particular by women, for they are responsible for collecting water. In addition to these specific benefits, several community members found the delimitation process itself empowering, because it gave them an opportunity to secure their land rights and also learn about how the law protects such rights. Canhane resident Jacinto Luís, for instance, explained that delimitation had greatly increased his knowledge of his land rights and that now " $[\mathrm{w}]$ hoever wants to make an investment in Canhane has to talk to us first. ... Helvetas came to add to our knowledge of land rights [and helped secure these rights] because we have a document that says we have all rights upon this land." Empowering the community by teaching its members about their land rights was, in fact, an explicit goal of Helvetas throughout the land-delimitation process (Palalane 2005).

Canhane's neighbor Cubo, in partnership with the African Wildlife Foundation (AWF), is working to build a community-based wildlife reserve. As part of the Limpopo Heartland conservation program, funded by USAID and implemented by the AWF, the Cubo project has a dual goal of stimulating socioeconomic development for the people of Cubo and restocking animal populations left devastated by the civil war (AWF 2005). One difference between this project and the Covane Lodge is that, from the outset, the AWF has been working with the people of Cubo to develop partnerships with private investors. One of the most senior project managers expressed deep skepticism that the people of Canhane would have the skills needed to run Covane Lodge on their own once Helvetas leaves. For the Cubo project he therefore found it more prudent to bring in private investors from the beginning. 
But as with the efforts of Helvetas, central to the mission of the Cubo project is the protection of community land rights under the land law. Highlighting the problematic potential of a landgrab I referenced above, the AWF explains:

\begin{abstract}
Already the anticipated benefits from tourism development due to improved wildlife populations in the GLTP have created major challenges. Various unscrupulous foreign investors have moved into the area and taken advantage of community ignorance and poverty to acquire large tracts [of] land. Some communities have lost land while many more stand to suffer the same fate. The Cubo Community was one of the most threatened because of its proximity to the GLTP. In order to safeguard community land and prepare the community to benefit from conservation and tourism development, AWF assisted the Cubo community to acquire land rights for their area. (AWF 2005)
\end{abstract}

And, with the AWF's assistance, Cubo was able to attain a title from the state for 12,000 hectares to turn into a wildlife reserve-a reserve open to private investment and for which the community's land rights are now legally protected as they negotiate with potential investors.

The Cubo project and the Covane Community Lodge, though both mediated by NGOs, are precisely the types of decentralized generators of economic development and community empowerment that many state and park representatives, as well as the architects of the land law, have promoted, in the sense that they both protect community land rights and stimulate decentralized economic growth. It is too early to determine whether these projects have succeeded in fulfilling their goals. But so far the projects have helped protect community rights, both legally and via education, and have opened the way for investment via tourist dollars (in both projects) and private investment (certainly in the Cubo project and very likely in the Canhane project as well). ${ }^{3}$

\title{
The Limpopo National Park, Land Dispossession, and Uneven Geographies of Neoliberal Land Reform
}

Although the measures enabled by the land law-in particular the protection of land rights via land delimitation and registration-have been welcomed in Canhane and other communities that are outside the LNP, the state of affairs within the LNP is starkly different. Presently, the park's administration is working to relocate the approximately 5,000-6,000 people living in areas designated as "tourist" or "wilderness" zones. Although the administration has promised no forced relocations-a promise also made by the LNP's primary funder, the German Development Bank (KfW) -it is developing incentive packages to compensate people for their land and strongly encouraging them to relocate either into concentrated, fenced enclave communities inside the park or, preferably, to areas outside it. The administration points out that it is dangerous for people to live with wild animals, a danger that will only increase as the park is restocked (Vicente, van Wyk, and Boshoff 2003; Vicente and van Wyk 2005). One of the communities slated for relocation is Massingir Velho, located just across the Massingir Reservoir from Canhane (see Figure 2). As I dis- 
covered during interviews with approximately ninety residents of Massingir Velho in 2004-2005, opinions about the park are mixed. Although some residents consider it a source of great economic potential, the majority are less convinced of its benefits, voicing concerns ranging from distrust of the state and its promises to fear of losing ancestral land and access to natural resources. Furthermore, even people who are relatively supportive of the project voice frustration that they were not adequately consulted before the park was created but, rather, were simply informed that they were living inside a national park (see also RRP 2002).

What interests me are the relationship and spatial juxtaposition between the park and community-development projects outside its borders. One tension that emerges from within and between these spaces is that, although the land law protects landuse rights outside the park via land-use certificates and titles, it simultaneously exempts the space of the park from having to grant or acknowledge these rights. More explicitly, though designed to protect community and individual rights to occupy and use land, to enable the transferability of these rights, and to promote private investment, the land law makes an explicit exception for zones of total or partial protection, like national parks. These are considered part of the public domain. The law specifies that no right to land use and benefit can be acquired in these areas, although one may be issued a license for a specific activity (Article 9, \$1-2; Article 10, $\$ 1-2)$. In fact, existing land rights can be terminated by the state for reasons of public interest, as long as the state pays adequate compensation (Article 19, $\$_{3}$ ). This exception is also endorsed by Article 111 of the 2004 Mozambican Constitution.

Emanating in part from concerns over the rights and well-being of rural communities - that is, many of the same concerns shaping the land law--a great deal of controversy has arisen in Mozambique regarding the rights of communities within national parks and other protected areas. Land analysts and even the World Bankproduced resettlement policy for the LNP (and other transfrontier parks and conservation areas in Mozambique) notes that other national laws, such as the 1997 forestry and wildlife law (No. 10/1997), grant some degree of community entitlement to protected areas. The resettlement policy, for instance, explains that the Forestry and Wildlife Law
identifies the principles of local community participation in sustainable natural re- sources management inside as well as outside of PAs [protected areas]. However whereas the Land Law does not permit any use of resources in PAs, the Forestry and Wildlife Law prohibits hunting, agriculture and livestock rearing in national parks which are protected areas, unless otherwise stipulated in a management plan. Indi- rectly the law recognises the presence of people in PAs when it stipulates that man- agement plans for PAs must be formulated with the collaboration of the local communities. It also emphasises that conservation and sustainable use [of] resources should harmonise with actions of the local authorities within the framework of de- centralization. (World Bank 2005, 6)

Some analysts, moreover, see an ambivalence in the land law itself regarding land rights in protected areas, especially for communities that have occupied land for 
more than ten years (Chilundo, Cau, and Filipe 2004; Norfolk 2004). Yet, even recognizing this confusion, the park administration is explicit in its position that the land law does not protect communities' land rights based on prior occupancy inside national parks. For instance, the resettlement policy states resolutely that

people who have spent more than 10 years [in protected areas like national parks] do not in fact have rights to use and benefit of the land safeguarded by their period of residence as might be implied by the Land Law. To the contrary, it clearly prohibits any legal rights to use of this land other than those of the State, unless a special license is granted. (World Bank 2005, 8)

Nevertheless, the resettlement framework goes on to explain that

local communities can secure a platform for benefit from the Wildlife and Forestry legislation entitling them to benefits from concession fees for use of land in PAs where they are "local communities," possibilities to participate in the creation of management plans, and the possibility to include certain uses of resources in PAs in the management plans that are prohibited by the Land Law. The nature of the "special license" identified in the Land Law that could permit use of land in PAs is not clear. (World Bank 2005, 8)

Senior members of the Transfrontier Conservation Areas arm of Mozambique's Ministry of Tourism (which oversees the transfrontier aspects of the LNP/GLTP) including its head, Bartolomeu Soto-endorse the view that rural communities may obtain such a "special license," as opposed to a title or a certificate. For instance, in response to my question about whether any demarcation of community land as specified by the land law exists inside the LNP, Soto replied:

It's technically impossible now because of the law. ... But what can still be done, is that where [communities] live, we can give them a concession. Because within certain areas people can get a concession but they cannot get a title [to] a piece of land. ... So whoever wants can negotiate with them.... But ... if we had [first] demarcated that land for the community, then everything would be a national park except the area where they live. That would be their own area. So they would also live in the area, but they would make a contract with the national park, saying, "This area is ours, but you can manage it for biodiversity conservation." (Soto 2005)

What we see here is that communities inside the park may be granted some entitlement to use land, yet this is not done (entirely) through the same mechanisms established in the land law. Rights guaranteed under the land law are legally much stronger and more secure than what Soto and the resettlement framework are suggesting; in fact, their suggestion is not based on a right at all but is, rather, a stategranted privilege. Thus the land law has been interpreted in a way-and, I think, the most literal way-that excludes the LNP as a space in which land rights based on prior occupancy are recognized; that is, the same rights the law guarantees in nonprotected areas.

Comparison of spaces inside and outside the park reveals a starkly uneven geography of neoliberal land reform. In spaces outside the park, the land law recog- 
nizes-indeed, establishes-community land rights, yet this same legal mechanism denies those rights inside the park. The space of the park is not only renationalized as it becomes a national park; it is renationalized in such a way that residents living inside its borders in villages like Massingir Velho are asked to leave, and those who want to stay have no legally recognized land rights with which to defend their claims. ${ }^{4}$ Hence the LNP, backed by the land law, promotes land dispossession in such communities. This is not, however, a simple case of uneven geographies in which community land-use rights are protected outside the park while denied inside its borders, as profound connections unite the two spaces. The very conditions of possibility of the community-development projects outside the park are rooted in the park itself-without the park no tourists would come, so no market would exist for lodges like the Covane Community Lodge or for ecotourist nature reserves like the Cubo project. In this sense, such projects designed to generate capital and hence economic development have been enabled not just by recognition of (transferable) land-use rights, as I discussed above. In fact, these projects, located outside the park, have been enabled by withholding these land rights within the park-that is, to the extent that the LNP has been created through the application of the land law that exempted it from having to recognize such land rights.

I am not certain that events had to have unfolded in this way. Why couldn't the LNP have been built "in partnership" with communities like Massingir Velho, which held land rights and agreed to lease the land to the state, as, for example, South Africa National Parks leases Makuleke land? Clearly establishing the LNP as a space that is exempt from recognition of land rights has given the park administration much greater decision-making power over the space and in this sense has allowed it to build the park as it has seen fit, with less "interference" from soon-to-be-displaced communities.

\section{The Limpopo National Park, Neoliberal Land Reform, and the Broader Scholarly Terrain}

The case of the LNP also points to tensions within Mozambique regarding community development, access to land and natural resources, and the role of the state in the context of ever-intensifying neoliberal economic and political reform. In fact, I would argue that debates over land reform in Mozambique have been to a large degree debates over the legitimate reach of state power, for example, into the economy. In this sense, the case speaks to larger scholarly debates regarding state power and neoliberal reforms, especially those concerning the privatization of land and natural resources. On one hand, the LNP fits somewhat awkwardly with such studies, but on the other hand, it reinforces their insights. Critics of neoliberal policies that have led to the privatization of land and natural resources have convincingly shown that such policies often lead to the dispossession of such assets, especially among the less powerful (Goldman 1998; Heynen and others 2007). The Mozambican land law and the resulting semiprivatization of land and natural resources so far seem to protect, not compromise, land rights for the rural poor, especially in the face of the rapid revaluation of land since the civil war and with the construction of 
the LNP as a tourist destination. ${ }^{5}$ It would be too strong, though, to say that it is simply the neoliberal components of the land law, especially those enabling semiprivatization, that offer such protection. Rather, it is these components as they articulate with the more populist mechanisms included in the law-for example, insistence that communities be made aware of their land-use rights and that communities, not just individuals, can hold such rights-that offer such protection.

Furthermore, examining how the land law has been applied to the LNP shows that land rights are presently being denied-and people are being asked to give up their land-within the park, a space that has been thoroughly nationalized, not privatized. The concern with neoliberal land reform and privatization in academic circles has overlooked the significance of such nationalized spaces by focusing primarily on privatized spaces and resources. At some level this makes complete sense, for neoliberal reforms have routinely demanded such privatization. In fact, it may seem as though we exited the realm of neoliberal land reform once we started looking at a case of land nationalization, given that the goal of many neoliberal reforms is precisely to limit the reach of the state. The renationalization of land that enabled the creation of the LNP was, however, a thoroughly neoliberal nationalization, as odd as that may sound. First, what has given the Mozambican state the power to nationalize land in a way that denies or overrides community land rights is the land law, clearly a legal apparatus born of and instituted to bring about Mozambique's larger neoliberal economic and political transformation. Second, the LNP has been built in large part precisely to attract foreign investment and generate economic growth within Mozambique and in this sense is very much a product of the broader drive to liberalize the Mozambican economy. Finally, though slightly less obvious, the park has been built as a means of enabling decentralized community-development projects-which often invite foreign investment-just beyond its borders, another tip of the hat to neoliberal reforms. My concern here is not that the scholarly literature on neoliberalism romanticizes the nationalization of land and natural resources or celebrates this as a more populist alternative to privatization. Rather, these scholarly debates tend simply to overlook how nationalization can lead to dispossession and how both are intricately tied to larger neoliberal reforms.

To extend the insights of this case a bit further, as a number of scholars have shown, in the 1980 os neoliberal reforms were often aimed at "rolling back" the power of the state. The 1990s, however, saw the state being restructured, reinstitutionalized, or rescaled, with state power consolidated in new ways; for instance, states often received increased power to protect and police property rights (Peck 2004; compare Harvey 2005). What we see with the LNP is an intensification of this process of consolidation of state power and, in addition, the production of a particularly interesting articulation of state and space embodied in a national park. Put simply, the LNP is what I call a "neoliberal state space"; that is, a space born of and created to institute neoliberal political and economic reforms and a space in which the state is the ultimate arbiter of what happens within the park's limits and thus not merely a space over which the state has strengthened its power. Thinking in terms of prop- 
erty, the park has been re-created as a form of explicit state property where citizens may have certain access to this space, but only as allowed by the state. ${ }^{6}$

At this point I think it is important to reply to a likely objection to this formulation of the LNP as a neoliberal state space, particularly an objection that reflects concerns commonly voiced by scholars who are familiar with Mozambique's aid dependency and with the foreign backing and promotion of large-scale development projects like the LNP/GLTP (compare Alden 2001; de Renzio and Hanlon 2007). Because the park is funded almost entirely by foreign aid institutions like the World Bank and the KfW, as well as by NGos such as the Peace Parks Foundation, what power does the Mozambican state actually have over the park? Isn't this another example of the neoliberal "hollowing out" of the state by international financial institutions and NGOS as they dictate to the state what it must do to continue the flow of assistance? So isn't talk of "state spaces" in this context misleading? Such concerns over state sovereignty have in fact been voiced in more practical terms by David Grossman, the head ecologist conducting the initial feasibility studies of the park (Groenewald 2002). In response, as I illustrate in much greater detail elsewhere (Lunstrum 2007), the Mozambican state has fundamentally been rebuilt-not crushed-through its association or "partnerships" with these institutions. The state is powerful, often precisely because of, not in spite of, these partnerships, offering insight into how Mozambican state power has been radically reshaped along neoliberal lines. These are the "partnerships," for example, through which the state gains the means necessary to build a park, relocate communities living inside its borders, bring in animals to repopulate the area, regulate the increasingly militarized space of the park through increasingly sophisticated surveillance technologies, and so forth. Hence, conceiving of the LNP as a state space is more than accuratealthough, admittedly, we would be wise to take seriously the complexities of what constitutes the Mozambican state and enables its governing capacities. And as I have attempted to show, the LNP is equally a neoliberal state space, one born of the neoliberal 1997 land law and one designed explicitly to attract foreign investment and promote decentralized economic development beyond its borders. ${ }^{7}$

\section{Notes}

1. Research for this project was conducted over eleven months in 2004-2005 in Maputo, Pretoria, and several villages in and near the LNP, including Massingir Velho and Canhane. Data were gathered during park-planning meetings and from more than 150 individual and group interviews. Interviews in Massingir Velho and Canhane were conducted in Shangaana by translators, so direct quotations from these interviews are translations.

2. For more information on the delimitation process, see Comissão Interministerial de Revisão da Legislação de Terras 2000.

3. Although given that Helvetas and the AWF are not private investors and are thus not concerned with (personal) financial gain, it is reasonable to question how generalizable or representative such applications of the land law are. But, presently, most land delimitations in Mozambique are in fact being carried out by NGOS that, like Helvetas and the AWF, often take an advocacy position. Moreover, the AWF is working hand in hand with private investors on the Cubo project.

4. In effect, this nationalization of land amounts to a form of privatization. Whereas the semiprivatization of land outside the park is one in which the state guarantees individuals/communities' 
rights to land, the nationalization-as-privatization of land inside the park is one in which the state denies such rights and does so in the name of promoting investment and national development.

5. This, however, could change if communities are not made aware of their rights or if the legal system does not protect such rights when they are challenged.

6. What the land law does in communities like Canhane and Cubo is render such communities legible to the state both geographically (for example, as their land enters the cadastre) and legally as they become (land) rights-holding entities (compare Tornimbeni 2007). As communities and their land rights are legible to the state only via such legislation, in areas where state power is seemingly devolved, such power is to some extent consolidated, as it forces communities to "play the land-rights game" by the rules set out by the state.

7. Parks in Africa (and elsewhere) have long been established via the nationalization of land and the related dispossession of communities that found themselves inside or simply too near park borders (Neumann 1998; Ramutsindela 2004). What I have illustrated is that such nationalization of land and dispossession in the LNP fits tightly within larger neoliberal transformations. To the extent that parks are built to enable decentralized, community-based development projects nearby and promote the accumulation and flow of capital by means of private investment (compare Wolmer 2003; Ramutsindela 2004), they too are neoliberal state spaces, a label the LNP alone does not merit.

\section{REFERENCES}

Alden, C. 2001. Mozambique and the Construction of the New African State: From Negotiations to Nation Building. London: Palgrave.

AWF [African Wildlife Foundation]. 2005. AWF Helps Cubo Community to Acquire Land Rights and Develop Community Reserve. African Heartland News, September-December, 3.

Borras, S. M., Jr. 2005. Can Redistributive Reform Be Achieved via Market-Based Voluntary Land Transfer Schemes? Evidence and Lessons from the Philippines. Journal of Development Studies 41 (1): 90-134.

Bowen, M. L. 2000. The State against the Peasantry: Rural Struggles in Colonial and Postcolonial Mozambique. Charlottesville: University Press of Virginia.

Chauque, F. 2004. Interview with the author. Canhane, Mozambique, 28 September.

Chilundo, A., B. Cau, and E. Filipe. 2004. Fortalecendo e agilizando o processo de delimitação e demarcação de terras das comunidades no Parque Nacional do Limpopo. Ministry of Tourism, Maputo, Mozambique.

Comissão Interministerial de Revisão da Legislação de Terras. 2000. Manual de delimitação de terras das comunidades. Comissão Interministerial de Revisão da Legislação de Terras, Maputo, Mozambique.

De Quadros, M. C. 2003. Current Land Policy Issues in Mozambique. Land Reform, Land Settlement, and Cooperatives, No. 3 (Special Issue): 175-200. [www.fao.org/docrep/006/y5026e/y5026eoc.htm \#bm12].

De Renzio, P., and J. Hanlon. 2007. Contested Sovereignty in Mozambique: The Dilemmas of Aid Dependence. University of Oxford, Managing Aid Dependency Project, Global Economic Governance Working Paper No. 2007/25. Oxford.

Fraser, A. 2007. Hybridity Emergent: Geo-History, Learning, and Land Restitution in South Africa. Geoforum 38 (2): 299-311.

Garvey, J. 1998. The Nature of Rights under Mozambique's Reform Land Law. In Proceedings of the International Conference on Land Tenure in the Developing World, with a Focus on Southern Africa. Cape Town, South Africa: University of Cape Town. Also available at [www.mekonginfo.org/mrc /html/capetown/cape21.htm].

GLTP [Great Limpopo Transfrontier Park]. 2008. Overview of the Great Limpopo Transfrontier Park [www.greatlimpopopark.com/].

Goldman, M., ed. 1998. Privatizing Nature: Political Struggles for the Global Commons. New Brunswick, N.J.: Rutgers University Press.

Groenewald, Y. 2002. Poaching Stymies Superpark. Main \& Guardian Online, 16 December, \$10, 10. [www.mg.co.za/articledirect.aspx?area $=\% 2$ finsight $\% 2$ finsight_national\&articleid=13452].

Hanlon, J. 2004. Renewed Land Debate and the "Cargo Cult" in Mozambique. Journal of Southern African Studies 30 (3): 603-625. 
Harvey, D. 2005. A Brief History of Neoliberalism. Oxford: Oxford University Press.

Helvetas. 2002. Community Based Tourism in Massingir District-Canhane Community Project: Participatory Rural Appraisal. Helvetas Mozambique, Maputo, Mozambique. [http://pdf.usaid.gov /pdf_docs/PDABZ191.pdf].

Heynen, $\vec{N}$., J. McCarthy, S. Prudham, and P. Robbins, eds. 2007. Neoliberal Environments: False Promises, and Unnatural Consequences. New York: Routledge.

Luis, J. [pseudo.]. 2005. Interview with the author. Canhane, Mozambique, 5 February.

Lunstrum, E. 2007. The Making and Un-Making of Sovereign Territory: From Colonial Extraction to Postcolonial Conservation in Mozambique's Massingir District. Ph.D. diss., University of Minnesota.

Macia, A. 2005. Interview with the author. Canhane, Mozambique, 4 February.

Magane, S., B. Soto, S. Munthali, S. Schneider, and others. 2003. Limpopo National Park Management and Development Plan, First Edition. Ministry of Tourism, Limpopo National Park Project, Maputo, Mozambique.

Neumann, R. 1998. Imposing Wilderness: Struggles over Livelihood and Nature Preservation in Africa. Berkeley: University of California Press.

Norfolk, S. 2004. Examining Access to Natural Resources, and Linkages to Sustainable Livelihoods: A Case Study of Mozambique. Food and Agriculture Organization, Livelihood Support Program Workjng Paper No. 28. Rome.

Palalane, G. 2005. Interview with the author. Maputo, Mozambique, 19 January.

Peck, J. 2004. Geography and Public Policy: Constructions of Neoliberalism. Progress in Human Geography 28 (3): 392-405.

Pitcher, M. A. 2002. Transforming Mozambique: The Politics of Privatization, 1975-2000. Cambridge, England: Cambridge University Press.

PPF [Peace Parks Foundation]. 2007. Great Limpopo (map). Peace Parks Foundation, Stellenbosch, South Africa. [www.peaceparks.org/gis.php?mid=251\&pid=158].

Ramutsindela, M. 2004. Parks and People in Postcolonial Societies: Experiences in Southern Africa. Dordrecht, Netherlands: Kluwer Academic Publishers.

RRP [Refugee Research Programme]. 2002. A Park for the People? Great Limpopo Transfrontier Park: Community Consultation in Coutada 16, Mozambique. University of the Witwatersrand, Refugee Research Programme, Acornhoek, South Africa. [www.queensu.ca/samp/migdocs/Documents /2002 /park.pdf].

SAHIMS [Southern African Human-Development Information Management Network for Coordinated Humanitarian \& Development Action]. 2008. Country Datasets \& Geographical Information: Mozambique. SAHIMS, Johannesburg, South Africa. [www.sahims.net/gis/Gis\%2oInput/ GIS_library_Regional_copy(1).asp].

Soto, B. 2005. Interview with the author. Maputo, Mozambique, 26 January.

Tanner, C. 2001. The Reform and Implementation of Land Policy in Mozambique-A Case Study of FAO Support. Land Reform, Land Settlement, and Cooperatives, No. 2: 4-15. [www.fao.org/DOCREP 1005/Y2519T/y2519to2.htm\#P12_2695].

- 2002. Law-Making in an African Context: The 1997 Mozambican Land Law. FAO Legal Papers Online, 26. [www.fao.org/Legal/prs-ol/lpo26.pdf].

- 2005. Interview with the author. Maputo, Mozambique, 28 January.

Tornimbeni, C. 2007. "Isto foi sempre assim": The Politics of Land and Human Mobility in Chimanimani, Central Mozambique. Journal of Southern African Studies 33 (3): 485-500.

Vicente, G., and A. van Wyk. 2005. Interview with the author. Maputo, Mozambique, 28 January.

Vicente, G., A. van Wyk, and P. Boshoff. 2003. Limpopo National Park Business Plan, Period 20042006. Ministry of Tourism, Limpopo National Park Project, Project Implementation Unit, Maputo, Mozambique.

Wolford, W. 2007. Land Reform in the Time of Neoliberalism: A Many-Splendored Thing. Antipode 39 (3): $550-570$.

Wolmer, W. 2003. Transboundary Conservation: The Politics of Ecological Integrity in the Great Limpopo Transfrontier Park. Journal of Southern African Studies 29 (1): 261-278.

World Bank. 1996. Transfrontier Conservation Areas Pilot and Institutional Strengthening Project: Mozambique. World Bank, Washington, D.C.

- 2005. Transfrontier Conservation Areas and Tourism Development Project: Mozambique. World Bank, Resettlement Policy Framework, Report No. 210205. Washington, D.C. 